\title{
Ecodesign - Carbon Footprint - Life Cycle Assessment - Life Cycle Sustainability Analysis. A Flexible Framework for a Continuum of Tools
}

\author{
Reinout Heijungs, Institute of Environmental Sciences, Leiden University
}

\begin{abstract}
Life cycle assessment (LCA) is a tool for answering questions related to environmental impacts of products. It is a comprehensive tool, addressing the entire life cycle, and addressing the full spectrum of environmental impacts. There are two opposite movements occurring: LCA is getting smaller, and it is getting broader. This presentation presents the general framework for a broader life cycle sustainability analysis (LCSA), and shows how the practical work related to doing an LCA, a carbon footprint, or an analysis for ecodesign, can be seen as special cases.
\end{abstract}

Keywords - life cycle sustainability analysis, life cycle assessment, carbon footprint, ecodesign.

\section{INTRODUCTION}

Life cycle assessment (LCA) has been defined by ISO as the "compilation and evaluation of the inputs, outputs and the potential environmental impacts of a product system throughout its life cycle" [1, p.2]. This is at the same time a narrow and a broad definition. It is narrow in the sense that it restricts the scope of LCA to environmental aspects only. Indeed, ISO explicitly adds that "LCA addresses the environmental aspects and impacts of a product system. Economic and social aspects and impacts are, typically, outside the scope of the LCA. Other tools may be combined with LCA for more extensive assessments" [1, p.7]. And it is broad in its explicit comprehensiveness: "LCA considers all attributes or aspects of natural environment, human health and resources. By considering all attributes and aspects within one study in a cross-media perspective, potential trade-offs can be identified and assessed" [1, p.7].

It is precisely the potential for trade-offs that induces a further broadening of LCA. Especially the case of biofuels presents a challenge here, for several reasons.

First, even though LCA is supposed to cover all environmental aspects, it is a well-established observation that not all environmentally relevant issues are included, and even when they are included, they are not always included in a meaningful way. Examples of poorly-covered issues are impact of land use and water use, deforestation, and dispersion of genetically modified organisms. Even the chemical-oriented problems - LCA's original strength - are of limited value for local problems, such as odour and toxicity.

Second, many of the problems that have been associated with biofuels do not show up in LCAs. Provision of food, dramatic increases of food prices, and violation of land property rights of farmers and indigenous peoples are some main examples here. This issue falls in the socio-economic domain, and is not part of the environmental LCA, and therefore fall outside LCA studies.

Third, even within the class of included environmental impact categories, oversimplifications yield an at least distorted picture. For instance, when the production of fuel crops takes place on land that was used before for the cultivation of food crops, food production may shift to other types of land. But the mechanisms that drive such consequences are beyond the scope of standard LCA.

Thus, we see that LCA is selected as an analytical tool because of its broad scope, but that for some key questions of contemporary policy it is certainly not broad enough. The tendency to broaden LCA is seen in the emergence of life cycle costing (LCC; see [2]), social life cycle assessment (SLCA; see [3]), and life cycle sustainability assessment (LCSA; see [4]). In a recent elaboration of the LCSA [5], the idea of a technological structure, linking the activities in a life cycle, with satellite data for environmental, economic and social performance, has been developed, thus essentially integrating the frameworks of LCA, LCC and SLCA; see also below.

At the same time, we see a wish to reduce the complexity and resource requirements of LCA. The most prominent example of this is the carbon footprint, which in most cases refers to an LCA-perspective with a single focus on climate change in terms of $\mathrm{CO}_{2}$-equivalents [6]. But the carbon footprint fits in a larger range of approaches that attempt to capture life cycle information in a tool that is simpler and/or quicker than LCA. Such simplified LCA tools can be categorized along various directions.

First, there are approaches that concentrate, like the carbon footprint, on a less complete set of impacts. There are approaches that concentrate on energy, or on resource requirements. The motivation for restricting the analysis to only a small set of impacts can be different. Sometimes, it follows from policy considerations, for instance when climate change has been declared to be the prime target. In other cases, there are heuristic reasons for simplifying. An example is the case of fossil power plants, where climate change and acidification are probably the most important impact types, and adding more impact categories would not really provide new insight while complicating the analysis. The carbon footprint is the most important example of this tendency to restrict the scope of LCA. The EU acknowledges that "The 
carbon footprint is a sub-set of the data covered by a more complete Life Cycle Assessment (LCA)" [6].

Second, there are approaches that do not focus on impact categories, but instead offer proxy indicators that are supposed to be correlated with the real impacts. For instance, fuel use, product mass, and amount of non-recyclable waste can be claimed to bear some relation to environmental impacts. Especially in the field of ecodesign, several tools have been developed to score alternative concepts and designs on such metrics. For instance, LCAs have been "simplified" to address categories such as MET (materials, energy, toxicity; see[7]), thus leaving out acidification, climate change, and so on.

In itself, the idea of an established theory with on the one hand pragmatic simplifications, and on the other hand theoretical abstraction, is an old idea. Newton's mechanics is simplified by engineers designing an elevator, and it is made more abstract by scientists working at relativity theory. The same situation is present for LCA: ecodesigners simplify, scientists make it more abstract. But the essential idea is that it is a continuum of approaches. The method for ecodesign should in the end be derivable from the standard LCA, and the standard LCA in its turn should be a limiting case of the more general LCSA.

This presentation presents the general framework for LCSA, and shows how the practical work related to doing an LCA, a carbon footprint or ecodesign, can be seen as special cases.

\section{THE FRAMEWORK FOR LCSA}

Life cycle sustainability assessment (LCSA) has been introduced by Klöpffer [4] as a way of combining the procedures and metrics of (environmental) LCA, life cycle costing (LCC), and social life cycle assessment (SLCA). Symbolically, they have been united as

$$
L C S A=L C A+L C C+S L C A
$$

This, however, represents more wishful thinking than a concrete tool. For instance, it has been noted [8] that the procedures for LCA and LCC are quite different with respect to several characteristics:

- time. LCA typically aggregates impacts along the entire life cycle, regardless of the time at which they occur. In LCC, it is practice to specify costs per year separately.

- definition of life cycle. LCA typically spans mining, production, use, and disposal. In LCC, R\&D activities and marketing are typically included.

- aggregation. LCA defines the sustainability in a crossgenerational perspective: the future is as important as the present. In LCC, the future counts typically less, by using a discounting rule.

Likewise, SLCA struggles to define the life cycle, the system boundaries, allocation, and other LCA-relevant steps in a way that is compatible with the conventions and practice of LCA [3].

There are two disadvantages associated with the set-up presented above:

- It is inefficient. Specifying a life cycle for LCA and a life cycle for LCC means duplicating a lot of work.

- It easily leads to inconsistencies. Setting boundaries and applying allocation rules should be done consistently across LCA, LCC and LCSA.

To resolve these issues, the CALCAS project [9] has proposed another conceptual framework for LCSA; see Fig 1.
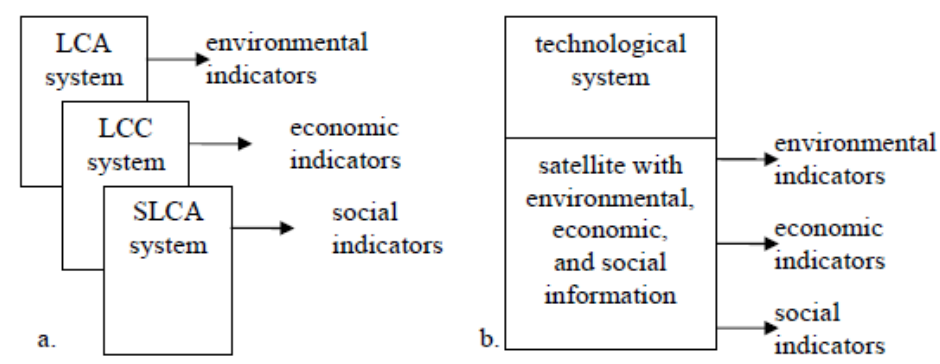

Fig. 1. Lay-out of a framework for life cycle sustainability analysis. a. presents the idea of Klöpffer [4], b. presents the idea of CALCAS. Source: $[10$, p.56].

That the framework for LCSA is different from those of LCA, LCC and SLCA can be seen by recognizing that the three underlying tools share a common part, referred to as the technological system in Fig. 1. This technological system represents the life cycle of the system under study. It captures all processes related to production, use, and disposal, but in principle also those related to marketing, R\&D. The technological system is in fact the main subject of LCI's inventory analysis. In ISO's structure for LCA and in the daily work of LCA practitioners, most of the effort goes into collecting data and modelling this technological system. It comprises activities, such as setting the system boundaries, choosing representative technologies, collecting data on inputs and outputs of products, materials, energy and waste, validation of data, allocation, and relating the data to the functional unit. The only aspect of the inventory analysis that does not fall in this technological system is the collection, validation, and processing of environmental data.

Let us have a look at the template for LCA in CML's Handbook on LCA [11]; see Fig. 2. 


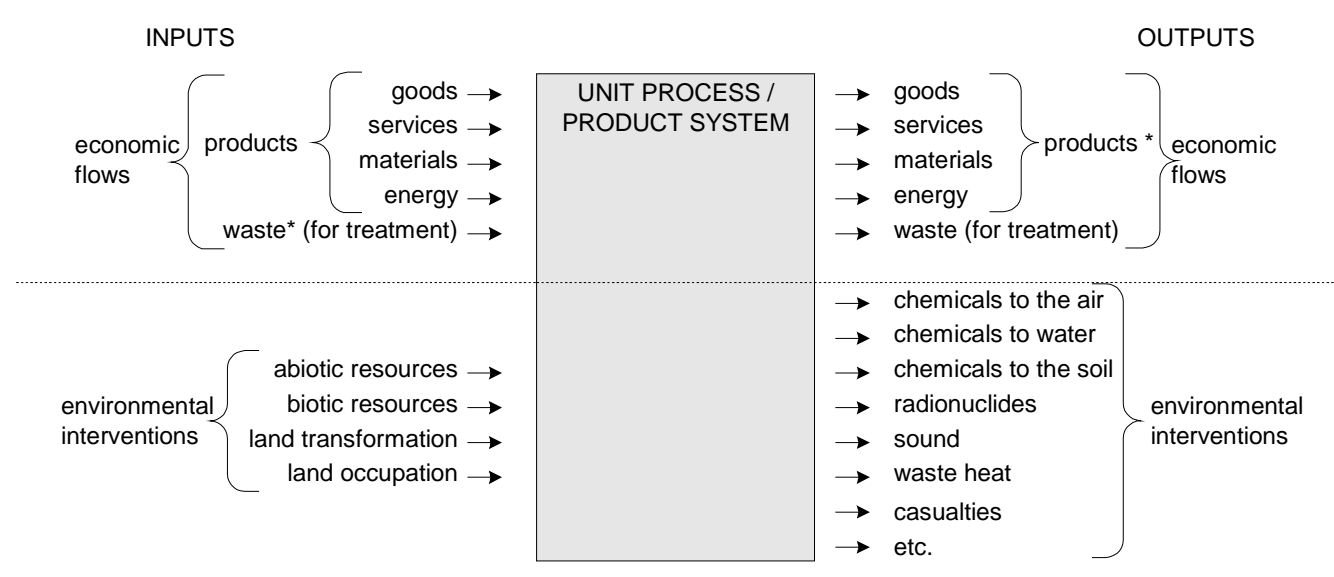

* functional flows

Fig. 2. Basic format for process data in LCA. Source: [11, p.479].

The process structure is divided into two main sections:

- the upper part having economic flows;

- the lower part having environmental flows.

The definition of these two sets has been elaborated in [12], p.20: "those which come from or go to another process (the economic flows), and those which come from or go to the environment (the environmental flows)". Comparison of Fig. 2 with Fig. 1 permits us to draw the synthesis in Fig. 3.

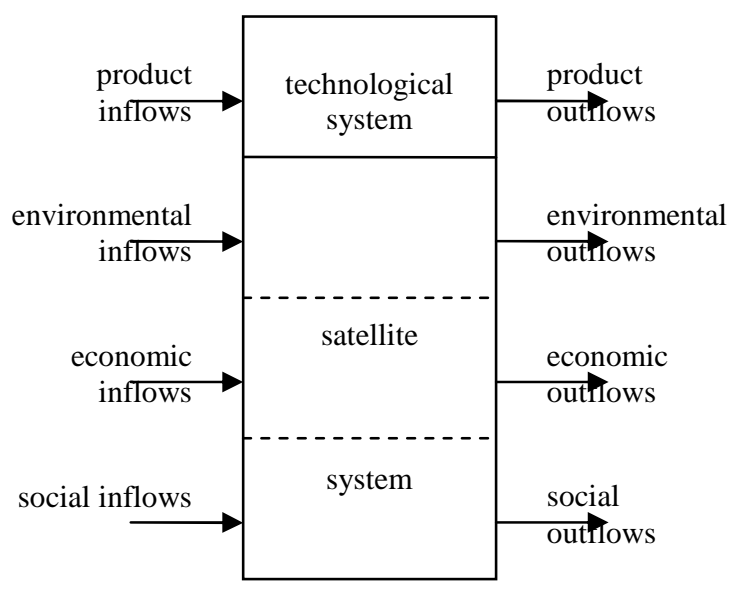

Fig. 3. Basic format for process data in LSCA, based on [5] and [11].

The term satellite in Fig. 1 is derived from input-output analysis (IOA) [13], where an inter-industry part is the core of the system, and one or more satellite accounts can be added, to cover energy, environment, materials, and other relevant items. There is, however, one more thing besides the inter-industry part and the satellites in IOA. These are referred to by different names: value added categories, factor inputs, primary inputs. Prime examples are labor, rent, royalties, taxes, and profit. From an environmental point of view, this information is not relevant. Indeed, the LCA template of Fig. 2 does not accommodate these items. From an economic and social point of view, however, these are of prime interest. They serve to establish life cycle costs and they help to identify aspects related to employment. In LCC and in SLCA, these items are therefore essential. In social LCA, there are in addition other items that may be of interest, for instance aspects of child labor and spendings on education and charity.

Of course, there are some unclear points in the framework. Is labor part of the social or of the economic satellite, or both? Is the economic information on rent on land fully corresponding to the environmental information on land use, or does it cover another type of information? Such details are to be clarified in due course. The prime message is unaffected:

- There is an upper part, the technological system, that contains information on inflows and outflows of products.

- There is a lower part, the satellite system, that contains information on three sets of flows: environmental items (like water and $\mathrm{CO}_{2}$ ), factor items (like labor and rent), and social items (like child labor and gender issues).

- The upper part is connected to the upper parts of other processes.

- The lower part forms the basis of calculating impact indicators (like climate change, employment, or income distribution).

It is possible to cast the framework in a mathematical formulation on the basis of the one in IOA or LCA; see [12].

Given a final demand vector $\mathbf{f}$ that specifies the functional unit, the technological system that defines the inter-process linkages is written as a technology matrix $\mathbf{A}$. To satisfy the final demand, all processes need to work on a certain level, indicated by scaling factors $\mathbf{s}$. These are found by

$$
\mathbf{S}=\mathbf{A}^{-1} \mathbf{f}
$$

where the superscript -1 refers to the inverse of a square nonsingular matrix.

The satellite system is written as a matrix B. It can be considered as a partitioned matrix [10, p.57]: 


$$
\mathbf{B}=\left(\begin{array}{c}
\underline{\mathbf{B}}_{e n v} \\
\underline{\mathbf{B}}_{\text {econ }} \\
\overline{\mathbf{B}}_{\text {soc }}
\end{array}\right)
$$

Applying the same scaling factors $\mathbf{S}$ on the satellite matrix $\mathbf{B}$, we can calculate the inventory results $\mathbf{g}$, again as a partitioned set of indicators:

$$
\mathbf{g}=\left(\begin{array}{l}
\mathbf{g}_{\text {env }} \\
\underline{\mathbf{g}}_{\text {econ }} \\
\mathbf{g}_{s o c}
\end{array}\right)=\left(\begin{array}{c}
\mathbf{B}_{\text {env }} \\
\overline{\mathbf{B}}_{\text {econ }} \\
\underline{\mathbf{B}}_{\text {coc }}
\end{array}\right) \mathbf{s}=\mathbf{B s}=\mathbf{B} \mathbf{A}^{-1} \mathbf{f} .
$$

The impact assessment phase translates the inventory results into impacts. Characterisation factors, such as global warming potentials, can be arranged in a matrix form [12], yielding a characterization matrix $\mathbf{Q}$. Using this characterization matrix the factual characterization step delivering a characterization result $\mathbf{h}$ proceeds through

$$
\mathbf{h}=\left(\begin{array}{l}
\mathbf{h}_{e n v} \\
\overline{\mathbf{h}}_{e c o n} \\
\overline{\mathbf{h}}_{s o c}
\end{array}\right)=\left(\begin{array}{ccc}
\mathbf{Q}_{e n v} & \mathbf{0} & \mathbf{0} \\
\mathbf{0} & \mathbf{Q}_{e c o n} & \mathbf{0} \\
\mathbf{0} & \mathbf{0} & \mathbf{Q}_{s o c}
\end{array}\right)\left(\begin{array}{l}
\mathbf{g}_{e n v} \\
\overline{\mathbf{g}}_{e c o n} \\
\mathbf{g}_{s o c}
\end{array}\right) \mathbf{S}=\mathbf{Q g}
$$

This concludes our conceptual and formal treatment of LCSA as a generalization of LCA.

\section{CONDENSING LCSA TO LCA}

Having generalized LCA is one step, but is there also a way back? Is it possible to derive LCA from LCSA as a limiting case, like we can derive Newton's mechanics from Einstein's more general theory? Yes, formally we can put all economic and social information to zero, and

$$
\mathbf{g}=\left(\begin{array}{c}
\mathbf{g}_{e n v} \\
\overline{\mathbf{0}}_{\text {econ }} \\
\hdashline \mathbf{0}_{s o c}
\end{array}\right)=\left(\begin{array}{c}
\mathbf{B}_{\text {env }} \\
\overline{\mathbf{0}}_{\text {econ }} \\
\hdashline \mathbf{0}_{s o c}
\end{array}\right) \mathbf{s}=\mathbf{B} \mathbf{s} .
$$

This will save us from collecting data on the economic and social satellite on the expense of not providing indicators for these aspects. But - and this is the crucial thing - the structure of the model is the same. We can use the same software and the same databases, but just "switch off" the economic and social satellite accounts. Fig. 3 shows a screenshot of the software CMLCA [14], where such switches have been literally built in.

\section{CONDENSING LCA To CF}

Typically, $\mathbf{h}_{e n v}$ contains climate change along with a number of other impact categories, such as toxicity and resource depletion. In such cases, we can thus write $\mathbf{h}_{e n v}$ as

$$
\mathbf{h}_{e n v}=\left(\begin{array}{l}
h_{\text {climate change }} \\
h_{\text {toxicity }} \\
h_{\text {resource depletion }} \\
\cdots
\end{array}\right)
$$

Reduction to a carbon footprint simply takes place by selecting only climate change as an impact category, effectively ignoring the characterization factors for all non-climate related impacts and/or ignoring the environmental satellite for other interventions than greenhouse gases.

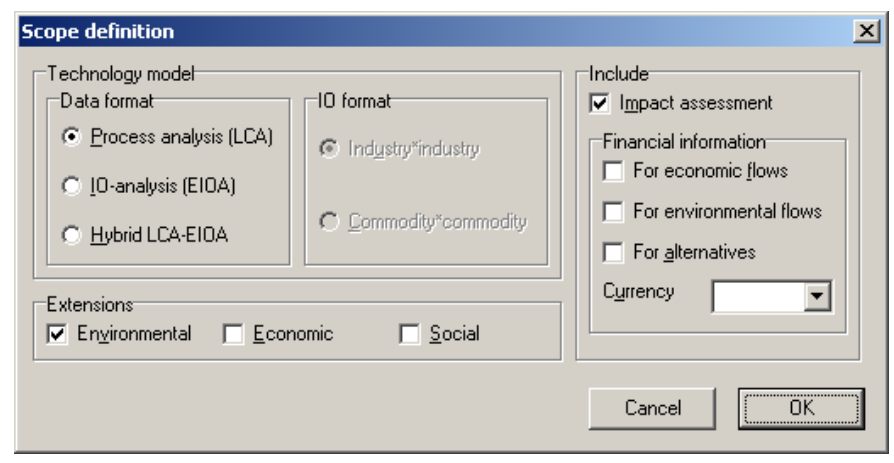

Fig 3. Screenshot from CMLCA, showing how an LCSA system may be simply reduced to an LCA system by ignoring the economic and social satellite accounts.

\section{V.CONDENSING CF TO ECODESIGN TOOLS}

Tools for ecodesign are of an essentially different character than LCA, whether in its extended LCSA or in its condensed CF form. Strictly speaking, they are not a scientific analysis, but practical rules of thumb, derived from scientific analyses by trial and error. For example, the MET approach [7] uses proxy indicators for materials, energy and toxicity as a pars-pro-toto of the total environmental burden. And although the EU directive [15] on ecodesign for energy-using products (EuPs) writes that "the energy consumption of EuPs in stand-by or off-mode should be reduced to the minimum necessary for their proper functioning", it at the same time acknowledges that a more complete analysis provides the ultimate benchmark: "Although a comprehensive approach to environmental performance is desirable, greenhouse gas mitigation through increased energy efficiency should be considered a priority environmental goal pending the adoption of a working plan." Thus, we see clearly the idea of practical rules of thumb, inspired by a combination of complete analysis and experience, and being subordinate in the end to a more comprehensive analysis.

\section{DISCUSSION AND PROSPECTS}

Simplifying is a process of omission: leaving out details, concentrating on a subset of aspects, reducing information. It is possible to derive a simple theory from a complex theory, but the converse is not possible. In that sense, the primacy for research is at LCSA, as the most comprehensive analysis.

Ordinary LCA and the carbon footprint can be derived from this more comprehensive analysis by a simple process of 
omission: skipping the economic and social dimension, or skipping all environmental impact except climate change. In that sense, we can consider this process of simplification as a projection. In a projection we map a description in many dimensions on fewer dimensions. For instance, a photo maps a situation in four dimensions (three spatial dimensions and time) on a situation in two dimensions (two spatial dimensions). The multi dimensional LCSA is mapped on a fewer dimensional LCA or a one dimensional $\mathrm{CF}$.

The derivation of ecodesign criteria proceeds in a different way. Here, it is not a simple projection, but the design of proxy indicators in a process of trial and error. In that sense, validation, or perhaps more appropriately using the Popperian paradigm [16], falsification, is an essential element of a continuing search and refinement of criteria for ecodesign. An interesting example of a crucial experiment is the test whether cumulative energy demand is an appropriate proxy indicator for the life cycle burden [17].

\section{ACKNOWLEDGMENTS}

The Netherlands Embassy in Riga has supported the author with a travel fund.

\section{REFERENCES}

1. ISO. Environmental management - life cycle assessment - principles and framework (ISO 14040). Geneva: ISO, 2006.

2. Hunkeler D., Lichtenvort K., Rebitzer G. Environmental life cycle costing. Pensacola: CRC Press, 2008.

3. UNEP. Guidelines for social life cycle assessment of products. Paris: UNEP, 2009.

4. Klöpffer W. Life cycle sustainability assessment of products. International Journal of Life Cycle Assessment 13:2 (2008), 89-94.

5. Heijungs R., Huppes G., Guinée J.B. Life cycle assessment and sustainability analysis of products, materials and technologies. Toward a scientific framework for sustainability life cycle analysis. Polymer Degradation and Stability 95:3 (2010), 422-428.

6. EU. Carbon footprint. What it is and how to measure it. http://lca.jrc.ec.europa.eu/Carbon footprint.pdf, 2007.

7. Berkel R. van, Willems E., Lafleur M. Development of an industrial ecology toolbox for the introduction of industrial ecology in enterprises - I. Journal of Cleaner Production 5:1-2 (1997), 11-25.

8. Huppes G., van Rooijen M., Kleijn R., Heijungs R. de Koning A., van Oers L. Life cycle costing and the environment. Leiden: CML, 2004.

9. CALCAS. Co-ordination Action for innovation in Life-Cycle Analysis for Sustainability. http://www.calcasproject.net/.

10. Heijungs R., Huppes G., Guinée J. A scientific framework for LCA. Deliverable (D15) of work package 2 (WP2) CALCAS project. Bologna: ENEA, 2009.

11. Guinée J.B., Gorrée M., Heijungs R., Huppes G., Kleijn R., de Koning A., van Oers L., Wegener Sleeswijk A., Suh S., Udo de Haes H.A., de Bruijn H., van Duin R., Huijbregts M.A.J. Handbook on life cycle assessment. Operational guide to the ISO standards. I: LCA in perspective. IIa: Guide. IIb: Operational annex. III: Scientific background. Dordrecht: Kluwer Academic Publishers, 2002.

12. Heijungs R., Suh S. The computational structure of life cycle assessment. Dordrecht: Kluwer Academic Publishers, 2002.

13. Miller R.E., Blair P.D. Input-output analysis: foundations and extensions. Englewood Cliffs: Prentice Hall, 1985.

14. CMLCA. http://www.cmlca.eu/.

15. EU. Directive 2005/32/EC of The European Parliament and of the Council of 6 July 2005 .

16. Popper K.R. Conjecture and refutations. The growth of scientific knowledge. London: Routledge, 1995.

17. Huijbregts M.A.J., Hellweg S., Frischknecht R., Hendriks H.W.M., Hungerbühler K., Hendriks A.J. Cumulative energy demand as predictor for the environmental burden of commodity production. Environmental Science \& Technology 44 (2010), 2189-2196.

Reinout Heijungs, Assistant Professor

Institute of Environmental Sciences, Faculty of Science, Leiden University

Address: PO Box 9518, 2300 RA, Leiden, Netherlands

Phone: 31-71-5277483, Fax: 31-71-5277434

e-mail: heijungs@cml.leidenuniv.nl

Reinout Heijungs. Ekodizains - Oglekḷa nospiedums - dz̄ves cikla novērtējums - dzīves cikla ilgstpējas analīze. Elastīga struktūra metožu nepārtrauktībai Dzīves cikla novērtējums (DCN) šobrīd ir plaši lietots instruments, lai atbildētu uz jautājumiem par produktu ietekmi uz vidi. DCN ir iecerēts kā visaptveroša metode, kas vērsta uz visu dzīves ciklu no produkta šūpuḷa līdz kapam, un aptver tā ietekmes uz vidi pilnu spektru, tostarp resursu sarukšanu, klimata pārmainas, toksiskumu uc. DCN attīstībā ir divas pretējās kustỉbas: DCN kḷūst šaurāks, un tas kḷūst arī plašāks.

Šaurāki DCN veikti jau kopš šīs metodes sākuma, vai pat agrāk. Faktiski DCN izauga no enerǵijas bilances analīzes, kur enerǵijas izmantošana bija vienīgais vērā nemtais faktors, un pakāpeniski šai analīzē sāka ieklaut arī citus faktorus, tādus, kā resursu patēriņu, siltumnīcefekta gāzu emisijas, toksisko vielu izmantošanu, utjpr. Ekodizaina mērḳiem DCN "vienkāršo", aptverot tādas kategorijas, kā, piemēram, materiāli, enerǵijas patēriņš, toksiskās vielas, tādējādi atstājot ārpus izpētes paskābināšanos, klimata pārmainas, un citus ietekmes uz vidi faktorus. Būtiskākais šādas pieejas ierobežojums, kam mūsdienu politika pievērš lielāko vērību, ir oglekla nospiedums.

Tendence paplašināt DCN ir novērojama, attīstoties tādām metodēm kā dzīves cikla izmaksu novērtējums (DCIN), dzīves cikla sociālais novērtējums (DCSN), un dzīves cikla ilgtspējas analīze (DCIA). Nesenā DCIA izstrādē ielikta ideja par tehnoloǵisko struktūru, kas savieno darbības dzīves ciklā ar pavadošajiem datiem par sniegumu vides, ekonomikas un sociālajā jomā.

Šì prezentācija sniedz pārskatu pār vispārējo dz̄ives cikla ilgtspējības analīzes (DCIA) struktūru un apskata praktiskos pētījumus, izmantojot DCN, ekodizaina, oglekḷa nospieduma metodes, kā atsevišķus DCIA gadījumus.

Рейноут Хейджунгс. Экодизайн - Выбросы углекислого газа - Оценка жизненного цикла - Оценка устойчивости жизненного цикла. Основа для непрерывного использования инструментов

В настоящее время оценка жизненного цикла (ОЖЦ) широко используется как инструмент, с помощью которого можно ответить на вопросы, связанные с влиянием отдельного продукта на окружающую среду. ОЖЦ была задумана как комплексный инструмент, обращённый на весь жизненный цикл продукта, от колыбели до могилы, и направленный на решение всего спектра влияния, который включает истощение ресурсов, изменение климата, токсичность и другое Существуют два противоположных движения: ОЖЦ становится меньше, и она становится всё шире.

Меньшая ОЖЦов проводилась с момента существования ОЖЦ, и даже дольше. По факту, ОЖЦ разивлась из энергетического анализа, где рассматривался аспект влияния на окружающую среду в результате потребления энергии, постепенно включая понятия ресурсов, парниковых газов, токсичности веществ и другое. Для целей экодизайна ОЖЦ была упрощена и направлена на такие категории, как материалы, энергия, токсичность, в результате чего были опущены понятия окисления, изменения климата и другие. Наиболее важные ограничения, которые зарождаются в современной политике, связаны с выбросами углекислого газа.

Тенденция расширения ОЖЦ проявляется в развитии сфер стоимости жизненного цикла (СЖЦ), социальной оценки жизненного цикла (СОЖЦ) и оценки устойчивости жизненного цикла (ОУЖЦ). В последние разработки ОУжЦ была включена идея технологической структуризации, которая связывает деятельность в жизненном цикле с помощью спутниковых данных об экологической, экономической и социальной деятельности.

Данная презентация представляет общие рамки для ОУЖЦ и показывает, как практические работы, связанные с развитием ОЖЦ, оценки выбросов углекислого газа или анализом для экодизайна могут быть рассмотрены как частные случаи. 